Kegiatan "Bersama Orang Tua” Terhadap Kreativitas Belajar Siswa ...

\title{
Kegiatan "Bersama Orang Tua" Terhadap Kreativitas Belajar Siswa SDN Tenggilis Mejoyo I Surabaya
}

\author{
M. Amin \\ FAI Unsuri Surabaya \\ Email; maminhasan@yahoo.co.id
}

\begin{abstract}
In the curriculum 2013 there are student activities with parents (formerly with homework/PR) is expected to develop and add activities according to the conditions and abilities of parents and students. Interaction between parents and students is very important to build a learning experience that can be at school an inseparable part of life at home. This study aims to find out how student activities with parents influence the learning creativity of first grade students at SDN Tenggilis Mejoyo I Surabaya. This type of research is quantitative, in collecting data using observation techniques and subjective tests with data analysis techniques using the percentage formula and Product Moment. The results found a positive relationship between activities with parents at home on student learning creativity with a pretty good correlation.
\end{abstract}

Keywords: Activities with parents and student learning creativity.

\section{A. Latar Belakang}

Pendidikan pada dasarnya merupakan tanggung jawab orang tua. Sedangkan sekolah/madrasah merupakan penyambung atau kepanjangan tangan dari peran orang tua. Sehingga tidak bisa dipisahkan secara dikotomis peran orang tua ketika anaknya sedang mengenyam pendidikan formal di sekolah, antara orang tua dan sekolah secara bersama-sama bertanggung jawab dalam mengawal perkembangan pendidikan anak.

Makna pendidikan tidaklah semata-mata kita menyekolahkan anak ke sekolah untuk menimba ilmu pengetahuan. Apalagi orang tua hanya cukup sekadar mengantar anak ke sekolah, namun lebih luas dari pada itu ${ }^{1}$. Pendidikan bagi anak yang merupakan

1. Dadang Hawari, Alquran Ilmu Kedokteran Jiwa dan Kesehatan Mental. (Jakarta: Dana Bhakti Yasa, 1997), 195.

144 | Jurnal Auladuna 


\section{Amin}

tanggung jawab orang tua telah tersurat dalam firman Allah SWT pada surat Luqman ayat ke tiga belas yang artinya: "dan (ingatlah) ketika Luqman berkata kepada anaknya, di waktu ia memberi pelajaran kepadanya: "Hai anakku, janganlah kamu mempersekutukan Allah, Sesungguhnya mempersekutukan (Allah) adalah benar-benar kezaliman yang besar". 2

Peserta didik atau siswa di dalam Kurikulum 2013, memang diarahkan supaya mandiri dan orang tua diharapkan terlibat aktif di dalamnya (buku siswa SD/MI kelas 1 tema 6: v). Hal ini sudah ditetapkan pada cara penggunaan buku siswa yaitu kegiatan bersama di rumah, peserta didik bersama orang tua dapat mengembangkan dan atau menambah kegiatan sesuai kondisi dan kemampuan orang tua dan peserta didik.

Proses pembelajaran dengan begitu dapat melakukan pergeseran paradigma, yaitu perubahan orientasi pembelajaran yang semula hanya berpusat pada guru (teacher centered) menjadi pembelajaran yang berpusat pada siswa (student centered). Siswa bisa bertanya kepada siapapun, kapanpun dan dimanapun. Disini diharapkan seorang guru harus menjadi fasilitator. Sehingga guru harus menciptakan suasana belajar yang melibatkan interaksi yang baik antara guru dengan siswa, siswa yang satu dengan siswa yang lainnya dan siswa dengan orang tuanya.

Salah satu kemampuan utama yang memegang peranan penting dalam kehidupan dan perkembangan peserta didik adalah kreativitas. Dalam upaya membantu peserta didik mewujudkan kreativitas mereka, peserta didik perlu dilatih dalam keterampilan tertentu sesuai dengan minat pribadinya dan diberi kesempatan untuk mengembangkan bakat atau talenta mereka. Pendidik terutama orang tua perlu merangsang pemikiran dan keterampilan kreatif anak serta menyediakan sarana dan prasarananya ${ }^{3}$.

SDN Tenggilis Mejoyo I Surabaya telah melaksanakan kurikulum 2013 dimana orang tua dilibatkan secara aktif dalam proses pembelajaran, terutama ketika di rumah. Peran orang tua untuk membantu membelajarkan anak di rumah dengan apa yang sudah dipelajari di sekolah demi memberikan pengalaman belajar lanjutan sesuai dengan kondisi anak. Pada usia uisa SD, anak menempati tahapan penting dalam perkembangan

${ }^{2}$ Kemenag RI., Al Qur'an dan Terjemahannya. (Semarang: CV. Toha Putra 2010).

${ }^{3}$ Utami Munandar, Pengembangan Kreativitas Anak Berbakat. (PT Rineka Cipta: Jakarta, 1999), 77.

145 | Jurnal Auladuna 
Kegiatan "Bersama Orang Tua” Terhadap Kreativitas Belajar Siswa ... dimana pada aspek apapun membutuhkan pondasi bagi perkembangannya pada usia selanjutnya.

Untuk itu penelitian ini bertujuan untuk melihat peranan orang tua dalam memfasilitasi atau mendampingi anak di rumah akan berimplikasi pada perkembangan anak terutama dalam mengembangkan kreatifitasnya. Adapun detiilnya terdeskripsikan pada rumusan berikut; (1) Bagaimanakah kegiatan bersama orang tua siswa SDN Tenggilis Mejoyo I Surabaya? (2) Bagaimana kreativitas belajar siswa SDN Tenggilis Mejoyo I Surabaya? (3) Adakah pengaruh kegiatan bersama orang tua terhadap kreativitas belajar siswa SDN Tenggilis Mejoyo I Surabaya?

\section{B. Metode Penelitian}

Penelitian ini menggunakan jenis penelitian kuantitatif dengan dengan jenis penelitian korelasi. Teknik pengumpulan data dengan beberapa cara yakni observasi, angket, dan tes subyektif ${ }^{4}$. Observasi digunakan untuk mengumpulkan informasi terkait kondisi obyektif lokasi penelitian. Angket/kuesioner digunakan untuk pengumpulan data responden tentang kegiatan bersama orang tua di rumah dan tes subjektif digunakan untuk mengukur kreativitas belajar siswa.

\section{Kajian Teori}

1. Kegiatan Bersama Orang Tua

Orang tua adalah orang yang bertanggung jawab dalam satu keluarga atau rumah tangga yang biasa disebut $\mathrm{ibu} /$ bapak $^{5}$. Orang tua hendaknya diartikan dalam konteks yang lebih luas, yaitu tidak hanya "orang tua" di rumah (sebagai ayah dan ibu), melainkan juga sebagai "orang tua" di luar rumah (sebagai anggota masyarakat, pejabat sipil maupun militer, pengusaha, agamawan, guru, dan profesi lainnya ${ }^{6}$.

${ }^{4}$ Sugiono, Metode Penelitian Kuantitatif, Kualitataif dan R \& D. (Bandung: Alfabeta, 2015), 16.

5 Thamrin Nasution dan Nurhalijah Nasution, Peranan Orang Tua Dalam Meningkatkan Prestasi Belajar Anak. (Yogyakarta: Kanisius, 1985), 1.

${ }^{6}$ Dadang Hawari: 235.

146 | Jurnal Auladuna 
Perhatian orang tua, terutama dalam hal pendidikan anak sangat diperlukan. Terlebih lagi yang harus difokuskan adalah perhatian orang tua terhadap kegiatan belajar yang dilakukan anak sehari-hari di rumah. Bentuk perhatian orang tua yang mempengaruhi keberhasilan kegiatan belajar anak, dapat dirumuskan sebagai berikut:

a. Pemberian bimbingan belajar

Bimbingan belajar terhadap anak berarti pemberian bantuan kepada anak dalam menghadapi segala masalah dalam belajarnya. Orang tua memberi petunjuk-petunjuk tentang cara-cara belajar, baik pula anak diawasi dan dibimbing sewaktu mereka belajar ${ }^{7}$.

b. Pengawasan terhadap belajar

Membantu kegiatan belajar anak salah satunya dengan memberikan pengawasan dalam belajar anak sangatlah dibutuhkan. Dengan pengawasan, minimal mereka bisa mengetahui ketika mempunyai kesulitan belajar. Di samping itu, orang tua yang peduli terhadap pengawasan belajar anaknya di rumah, juga bisa membantu kesulitan belajar lainya ${ }^{8}$.

c. Pemberian penghargaan dan hukuman

Orang tua seharusnya memberikan penghargaan dan pujian kepada anak atas kemampuan yang telah dicapai. Bentuk lain dari penghargaan adalah hadiah. Hadiah adalah sesuatu yang diberikan kepada orang lain sebagai penghargaan atau cenderamata. Hadiah yang diberikan orang lain bisa berupa apa saja, tergantung dari keinginan pemberi. Atau bisa juga disesuaikan dengan prestasi yang dicapai oleh seseorang 9 .

Namun kadang kala orang tua juga dapat menggunakan hukuman, Hukuman adalah reinforcement atau penguatan yang negatif tetapi diperlukan dalam pendidikan. Hukuman dimaksudkan di sini tidak seperti hukuman penjara atau hukuman potong tangan. Tetapi adalah hukuman yang bersifat

7 Slameto, Belajar dan Faktor-Faktor yang Mempengaruhinya. Jakarta: Rineka Cipta, 2015), 74.

8 Slameto: 74.

${ }_{9}$ Syaiful Bachri Djamarah \& Aswan Zain, Strategi Belajar Mengajar (Jakarta: Rineka Cipta, 2014), 150.

147 I Jurnal Auladuna 
Kegiatan "Bersama Orang Tua” Terhadap Kreativitas Belajar Siswa ... mendidik. Hukuman yang mendidik inilah yang diperlukan dalam pendidikan ${ }^{10}$.

d. Pemenuhan kebutuhan belajar

Kebutuhan belajar adalah segala alat dan sarana yang diperlukan untuk menunjang kegiatan belajar anak. Kebutuhan tersebut bisa berupa ruang belajar anak, seragam sekolah, buku-buku, alat-alat belajar dan lain-lain. Pemenuhan kebutuhan belajar ini sangat penting bagi anak, karena akan dapat mempermudah belajarnya ${ }^{11}$.

e. Menciptakan suasana belajar yang tenang dan tentram

Orang tua harus menciptakan ruang dan suasana rumah yang aman dan nyaman ketika anak sedang belajar, sehingga anak tidak merasa terganggu. Suasana rumah yang gaduh dan ramai tidak akan memberi ketenangan kepada anak yang sedang belajar. Rumah yang bising dengan suara radio, tape recorder, TV, suara penghuni rumah yang ribut, maupun suara pertengkaran orang tua pada waktu belajar, dapat mengganggu konsentrasi belajar anak ${ }^{12}$.

f. Memperhatikan kesehatan anak

Orang tua harus memperhatikan makanan yang dimakan anak, gizi makanan yang diberikan, istirahat anak, dan kesehatan badan yang lainnya. Selain itu juga memeriksakan anak ke dokter atau Puskesmas terdekat ketika anak sakit. Saat kesehatan anak baik maka kegiatan belajar anakpun akan berjalan dengan baik dan memungkinkan anak mendapatkan hasil belajar yang maksimal ${ }^{13}$.

Setiap akhir pembelajaran pada tiap subtemanya di buku tematik terpadu kurikulum 2013, terdapat kolom untuk orang tua dengan subjudul "kegiatan Bersama Orang Tua". Kolom ini berisi aktivitas belajar yang dapat dilakukan peserta didik bersama orang tua di rumah. Sampai saat ini banyak di antara wali murid yang masih sering menyebutnya dengan pekerjaan rumah (PR).

${ }^{10}$ Syaiful dan Aswan: 156.

${ }^{11}$ Slameto: 63.

12 Slameto: 63.

13 Slameto: 63.

148 | Jurnal Auladuna 
Pada setiap buku siswa terdapat bagian "Belajar di Rumah" yang berisi kegiatan yang harus dilakukan peserta didik bersama orang tua. Orang tua diharapkan peran aktifnya dalam rangka membimbing anaknya untuk melakukan aktifitas pembelajaran di rumah $^{14}$.

Dari penjelasan di atas dapat diketahui bahwa usaha dan berbagai bentuk perhatian orang tua dapat mendukung kelancaran dan keberhasilan kegiatan belajar sehingga dapat mempengaruhi kreativitas belajar anak. Zaman globalisasi ini, orang tua yang biasanya sibuk bekerja, sekarang harus menyempatkan diri untuk menempatkan diri di dalam keterlibatan pembelajaran anak.

Peran orang tua untuk membantu membelajarkan anak di rumah dinyatakan secara eksplisit di buku siswa. Hal ini mengingatkan bahwa orang tua harus mengambil bagian dalam pembelajaran tematik dan orang tua diajak terlibat serta mendorong kreativitas dalam pembelajaran peserta didik di rumah ${ }^{15}$.

${ }^{14}$ Kementrian Pendidikan dan kebudayaan, Buku Guru Kelas I, Tema 1: Diriku, Buku Tematik Terpadu Kurikulum 2013, Edisi Revisi 2017, 16.

${ }^{15}$ Kementrian Pendidikan dan kebudayaan, Buku Siswa Kelas I, Tema 1: Diriku, Buku Tematik Terpadu Kurikulum 2013, Edisi Revisi 2017, 4.

149 | Jurnal Auladuna 
Kegiatan "Bersama Orang Tua” Terhadap Kreativitas Belajar Siswa ...

2. Kreativitas Belajar Siswa

Kreatif adalah kemampuan untuk memberikan serangkaian alternatif jawaban terhadap suatu pertanyaan atau stimulus ${ }^{16}$. Sedangkan Nana Syaodih Sukmadianata mengartikan kreativitas adalah "kemampuan yang dimiliki seseorang untuk menemukan dan menciptakan sesuatu hal baru, cara-cara baru, model baru yang berguna bagi dirinya dan masyarakat" ${ }^{\text {"17 }}$.

Kreativitas adalah hasil interaksi antara individu dan lingkungannya, kemampuan untuk membuat kombinasi baru, berdasarkan data, informasi, atau unsur-unur yang sudah ada atau dikenal sebelumnya, yaitu semua pengalaman dan pengetahuan yang telah diperoleh seseorang selama hidupnya baik itu di lingkungan sekolah, keluarga, maupun dari lingkungan masyarakat ${ }^{18}$.

Ciri-ciri orang kreatif dalam dua kelompok, yaitu ciri-ciri kognitif (kemampuan berpikir) dan ciri-ciri afektif. Ciri-ciri kognitif meliputi kelancaran, fleksibilitas (kelenturan), dan orisinalitas di dalam berpikir. Sedangkan ciri non kognitif dari kreativitas meliputi motivasi, kepribadian, dan sikap kreatif. Krativitas baik itu yang meliputi ciri kognitif maupun non-kognitif merupakan salah satu potensi yang penting untuk dipupuk dan dikembangkan ${ }^{19}$.

Jika ditanya apakah belajar itu? maka jawaban yang akan kita dapatkan akan sangat beragam. Hal yang demikian ini berakar pada kenyataan bahwa apa yang di sebut perbuatan belajar itu adalah bermacam-macam. Merumuskan devinisi mengenai belajar bukanlah merupakan permasalahan yang sangat mudah, karena itulah devinisi yang kita jumpai akan banyak sekali.

Belajar pada hakikatnya adalah proses interaksi antara peserta didik dengan lingkungannya, sehingga terjadi perubahan perilaku kearah yang lebih baik ${ }^{20}$. Belajar adalah proses usaha yang dilakukan seseorang untuk memperoleh

${ }^{16}$ Seto Mulyadi, Seri Psikologi Anak 4 Memacu Bakat dan Kreativitas. (Jakarta: PT Gramedia, 2000), 21.

17 Nana Syaodih Sukmadianata, Landasan Psikologis Proses Pendidikan. Bandung: Remaja Rosda Karya, 2011), 104

18 Utami Munandar, Pengembangan Kreativitas Anak Berbakat. (Jakarta: PT Rineka Cipta, 1999), 12.

${ }^{19}$ Utami Munandar: 10.

${ }^{20}$ Mulyasa, Kurikulum Berbasis Kompetensi. Cetakan keduabelas. (Bandung: PT Remaja Rosdakarya, 2012), 100.

150 | Jurnal Auladuna 
perubahan tingkah laku yang baru secara keseluruhan, sebagai hasil pengalamannya sendiri dalam interaksi dengan lingkungannya ${ }^{21}$.

Belajar adalah "diperolehnya kebiasaan-kebiasaan, pengetahuan dan sikap baru"22. Sedangkan menurut Hilgard pada buku dan halaman yang sama, belajar adalah "suatu proses di mana suatu perilaku muncul atau berubah karena adanya respons terhadap suatu situasi”. Belajar adalah suatu aktifitas atau suatu proses untuk memperoleh pengetahuan, meningkatkan keterampilan, memperbaiki perilaku, sikap, dan mengokohkan kepribadian ${ }^{23}$.

Dalam penelitian ini bukanlah kegiatan belajarnya tetapi krativitas belajar atau daya cipta berupa karya peserta didik yang diteliti. Peneliti akan mengetahui apakah ada perbedaan kreativitas belajar pada peserta didik yang di dampingi orang tua dalam belajar secara intensif dan efektif, tidak intensif tapi efektif dan atau intensif tetapi tidak efektif, jika ada manakah yang lebih baik diantara peserta didik tersebut.

Dari uraian di atas maka kreativitas belajar yang di maksud dalam penelitian ini adalah proses pembelajaran dimana siswa difasilitasi untuk mengekspresikan dan mengaktualisasikan diri terkait dengan interaksi dengan dirinya sendiri, orang lain dan lingkungan sekitar yang hasilnya adalah menemukan serta menciptakan sesuatu yang baru berupa karya siswa.

\section{Hasil Penelitian}

Setelah mendata jumlah jawaban setiap pernyataan pada lembar kuesioner maka, untuk menjawab masalah yang pertama yaitu tentang bagaimana Kegiatan Bersama Orang Tua Siswa di SDN Tenggilis Mejoyo I Surabaya, dapat diketahui dengan memprosentase banyaknya nilai hasil jawaban dari 20 butir pernyataan dengan menggunakan rumus prosentase.

Hasil perhitungan yang diperoleh dari hasil kuesioner kegiatan bersama orang tua di SDN Tenggilis Mejoyo I Surabaya, yang dinilai oleh peneliti, secara umum dapat

${ }^{21}$ Slameto: 2

${ }^{22}$ Nana Syaodih Sukmadinata, Landasan Psikologis Proses Pendidikan. (Bandung: Remaja Rosda Karya, 2011) 155-156.

${ }^{23}$ Suyono dan Hariyanto, Belajar dan Pembelajaran (Bandung: PT Remaja Rosdakarya, 2011), 9.

151 | Jurnal Auladuna 
Kegiatan "Bersama Orang Tua” Terhadap Kreativitas Belajar Siswa ... digambarkan bahwa penerapan kegiatan bersama orang tua di SDN Tenggilis Mejoyo I Surabaya, berada pada kategori kuat. Hal ini dapat dilihat dari hasil prosentase observasi siswa yang berjumlah $70.6 \%$ apabila diinterpretasikan menggunakan tabel standar prosentase Sugiono ${ }^{24}$ maka prosentase $60 \%$ - 79\% yang dikategorikan kuat.

Untuk menjawab masalah yang ke dua yaitu tentang bagaimana kreativitas belajar siswa di SDN Tenggilis Mejoyo I Surabaya, dapat diketahui dengan memprosentase banyaknya nilai hasil jawaban dari empat butir soal tes subyektif yang dikerjakan siswa.

Hasil perhitungan yang diperoleh dari hasil tes kreativitas belajar siswa di SDN Tenggilis Mejoyo I Surabaya, yang dinilai oleh peneliti dengan standart pensekoran yang telah ditentukan sebelumnya, secara umum dapat digambarkan bahwa kreativitas belajar di SDN Tenggilis Mejoyo I Surabaya, berada pada kategori sangat kuat. Hal ini dapat dilihat dari hasil prosentase observasi siswa yang berjumlah $88,24 \%$. Apabila diinterpretasikan menggunakan tabel standar prosentase, maka prosentase di antara $80 \%$ - 100\% yang dikategorikan sangat kuat.

Selanjutnya untuk menganalisis hasil perhitungan pengaruh kegiatan bersama orang tua terhadap kreativitas belajar siswa yang berdasarkan tabel Koefisien Product Moment, peneliti memperoleh angka-angka yang hasilnya kemudian dimasukkan ke dalam rumus Korelasi Product Moment ${ }^{25}$.

Hasil analisis data berdasarkan koefisien Korelasi Product-Moment dari perhitungan tersebut telah diperoleh nilai $r_{x y}$ sebesar 0,403 selanjutnya, nilai $r_{x y}=$ 0,403 dikonsultasikan pada tabel nilai koofisien korelasi product moment $\mathrm{N}=59$ maka $\mathrm{r}$ tabel pada taraf signifikan $5 \%: \mathrm{rt}=0,254$ sedangkan pada taraf signifikan $1 \%: \mathrm{rt}=$ 0,330 .

Dari hasil konsultasi tersebut dapat diketahui $r_{x y}$ lebih besar dari $\mathrm{r}$ tabel, baik pada taraf signifikan 5\% maupun pada taraf signifikan $1 \%$ yakni $0,254<0,403>0,330$. Maka dari hasil yang perhitungan ini berarti ada hubungan antara variabel $\mathrm{X}$ dan

24 Sugiyono: 184.

${ }^{25}$ Suharsimi Arikunto, Prosedur Penelitian Suatu Pendekatan Praktik (Jakarta: PT. Rineka Cipta, 2014), 102.

152 | Jurnal Auladuna 


\section{Amin}

variabel Y. Berarti hipotesis kerja (Ha) yang menyatakan bahwa "Ada pengaruh kegiatan bersama orang tua terhadap kreativitas belajar siswa SDN Tenggilis Mejoyo I Surabaya" diterima. Dan Hipotesis nol (Ho) yang menyatakan bahwa "Tidak ada pengaruh kegiatan bersama orang tua terhadap kreativitas belajar siswa SDN Tenggilis Mejoyo I Surabaya" ditolak.

Langkah paling akhir yaitu untuk mengetahui sejauh mana pengaruh kegiatan bersama orang tua terhadap kreativitas belajar siswa di SDN Tenggilis Mejoyo I Surabaya dengan hasil $\mathrm{rxy}=0,403$ dikonsultasikan pada tabel interpretasi nilai $\mathrm{r}$ (Anas Sudijono, 2012: 193), maka rxy=0,403 berada diantara $0,40-0,70$ yang berarti "sedang".

\section{E. Penutup}

Berdasarkan hasil kajian teori dan analisis di atas dapat disimpulkan bahwa adanya pengaruh kegiatan bersama orang tua terhadap kreativitas belajar siswa SDN Tenggilis Mejoyo I Surabaya dengan tingkat pengaruh yang "sedang". Sehingga dapat disimpulkan bahwa semakin tinggi intensitas kegiatan belajar bersama orang tua di rumah dapat lebih meningkatkan daya kreativitas belajar siswa.

Kreativitas penting untuk dimunculkan, dan dikembangkan dalam diri anak sehingga memungkinkan bagi anak untuk mengembangkan dan meningkatklan kualitas hidupnya, dan peran orang tua sangatlah dibutuhkan. Melalui kegiatan bersama orang tua yang di dalamnya terdapat lebih banyak perhatian dan interaksi antara orang tua dan siswa, maka kegiatan-kegiatan tersebut dapat meningkatkan kemampuan kreativitas belajar siswa di SDN Tenggilis Mejoyo I Surabaya.

\section{F. Daftar Pustaka}

Arikunto, Suharsimi. 2014. Prosedur Penelitian Suatu Pendekatan Praktik. Jakarta: PT. Rineka Cipta.

Djamarah, Syaiful Bachri \& Zain, Aswan. 2014. Strategi Belajar Mengajar. Jakarta: Rineka Cipta.

Ghazali, Imam dkk. 2014. Al Mumayyaz Alqur'an Tajwid Warna Transliterasi Per Kata Terjemah Per Kata. Bekasi: Cipta Bagus Segara. 
Kegiatan "Bersama Orang Tua” Terhadap Kreativitas Belajar Siswa ...

Hawari, Dadang. 1997. Al-Qur'an: Ilmu Kedokteran Jiwa dan Kesehatan Jiwa. Yogyakarta: PT Dana Bhakti Prima Yasa

Kemenag RI. 2010. Al Qur'an dan Terjemahannya. Semarang: CV. Toha Putra.

Kementrian Pendidikan dan kebudayaan. Edisi Revisi 2017. Buku Guru Kelas I, Tema 1: Diriku, Buku Tematik Terpadu Kurikulum 2013.

Kementrian Pendidikan dan kebudayaan. Edisi Revisi 2017. Buku Siswa Kelas I, Tema 1: Diriku, Buku Tematik Terpadu Kurikulum 2013.

Mulyadi, Seto. 2000. Seri Psikologi Anak 4 Memacu Bakat dan Kreativitas. Jakarta: PT Gramedia.

Mulyasa. 2012. Kurikulum Berbasis Kompetensi. Cetakan keduabelas. Bandung: PT Remaja Rosdakarya.

Munandar, Utami. 1999. Pengembangan Kreativitas Anak Berbakat. Jakarta: PT Rineka Cipta.

Slameto. 2010. Intelegensi Pembelajaran Pada Anak. Jakarta: Balai Pustaka.

Slameto. 2015. Belajar dan Faktor-Faktor Yang Mempengaruhinya. Jakarta: Rineka Cipta.

Sudijono, Anas. 2012. Pengantar Statistik Pendidikan. Jakarta: PT Raja Grafindo Persada.

Sugiyono. 2015. Metode Penelitian Kuantitatif, Kualitataif dan R\&D. Bandung: Alfabeta.

Sukmadinata, Syaodih Nana. 2011. Landasan Psikologis Proses Pendidikan. Bandung: Remaja Rosda Karya

Suyono, Hariyanto. 2011. Belajar dan Pembelajaran. Bandung: PT Remaja Rosdakarya,

Nasution, Thamrin dan Nurhalijah Nasution. 1985. Peranan Orang Tua Dalam Meningkatkan Prestasi Belajar Anak. Yogyakarta:

Kanisius. 